УДК 94 (477.87) «19»

DOI: https://doi.org/10.33782/eminak2021.2(34).523

\title{
РОЛЬ ЗАКАРПАТСЬКОЇ ПОЛІТИЧНОЇ ТА ДУХОВНОЇ ЕЛІТИ У ПРОГОЛОШЕННІ «КАРПАТСЬКОЇ УКРАЇНИ»
}

\author{
Андрій Сініцький \\ Поліський національний університет (Житомир, Україна) \\ e-mail: andriysinc@gmail.com \\ ORCID: https://orcid.org/0000-0002-6482-4055
}

\begin{abstract}
У статті досліджено участь закарпатської політичної та духовної еліти у процесі проголошення, розбудови й захисту Карпатської України. Спираючись на принципи історизму, а також комплексності та наукової об'єктивності, автор статті здійснив осмислення конкретно-історичних передумов формування закарпатської політичної та духовної еліти у геополітичних процесах початку XX ст. Окреслено детермінуючі фактори, що спричинили особливості політичної диференціації та суспільної сегментації політичної еліти Закарпаття досліджуваного періоду, на основі чого здійснено характеристику сегментного складу та функціональних особливостей політичної й духовної еліти Закарпаття у період між двома світовими війнами.
\end{abstract}

Ключові слова: Карпатська Україна, політична еліта, духовна еліта, державотворення

Постановка проблеми. Історичний поступ українського державотворення у XX ст. $€$ фундаментом сучасних, часом складних і трагічних для України, суспільнополітичних процесів, що наглядно продемонстровано російською воєнною агресією, яка триває і по сьогодні. Інколи причиною таких процесів є слабкість державних інституцій, які формуються та забезпечуються політичною елітою, проте історія України наповнена прикладами консолідації та мобілізації політичних еліт, які у надскладних геополітичних умовах здійснювали ефективні заходи у сфері державотворення. Саме таким прикладом слід вважати один з етапів відновлення української державності у XX ст. - проголошення й оборону Карпатської України державного утворення, яке сконцентрувало навколо процесу свого відродження різноманітних представників політичної та духовної еліти українського Закарпаття, котре перебувало у складі міжвоєнної Чехословаччини й у подальшому внаслідок її розподілу було окуповано Угорщиною. Тому досвід ефективної державотворчої діяльності представників політичної та духовної еліти Карпатської України $€$ важливою й актуальною науковою проблемою з огляду на потребу її осмислення у сучасних умовах державотворення, коли Україна перебуває у стані захисту територіальної цілісності та державного суверенітету, що потребує консолідованих зусиль сучасних представників політичної і духовної еліти держави.

Стан наукової розробки проблеми. Науковий доробок історії Карпатської України, етапів її формування й обставин угорської окупації широко представлений у наукових розробках монографічного та епізодичного характеру такими вченими, як І.В. Буковський, М.М. Вегеш, С.В. Віднянський, О.Д. Довганич, Л.Л. Ковач, В.В. Петрецький, Ю.В. Славік, П.М. Ходанич, Л.В. Цубов та іншими. 
Зокрема, у дисертації І.В. Буковського ${ }^{1}$ досліджено вплив політичної еліти Закарпаття на процес утворення та діяльності військових формувань Карпатської України. Окремо слід відзначити численні фундаментальні дослідження M.M. Вегеша, який приділив дослідницьку увагу як процесу державотворення у Закарпатті, так і окремим персоналіям. М.М. Вегеш досліджував державотворчі процеси у Карпатській Україні ${ }^{2}$, разом з С.В. Віднянським ${ }^{3}$ представив монографічне дослідження ролі та значення Августина Волошина в історії українського державотворення й оборони Карпатської України. Логічним продовженням даних досліджень стала публікації Ю.В.Славіка та О.Довганича4, присвячена репресіям проти їі оборонців і керівників Карпатської України, де висвітлено подальшу трагічну долю представників політичної та духовної еліти Закарпаття, які очолили державотворчі процеси у краї.

Історіографічний блок історії політичної та духовної еліти Карпатської України показано у дослідженнях 0.Ковач5, де проаналізовано дану проблему в оцінках вітчизняних і зарубіжних науковців. В. Петрецький ${ }^{6}$ висвітлив проблеми консолідації еліти Закарпатті міжвоєнного періоду й охарактеризував чинники, що вплинули на ці процеси. Консолідація політичної та духовної еліти охарактеризована у дослідженні Л.В. Цубова7, який представив даний процес в еволюційному розрізі динаміки державотворчих процесів міжвоєнного періоду.

Водночас, зважаючи на наявність достатньо значного масиву досліджень проблем українського державотворення у Закарпатті кінця 1930-х років, варто констатувати малодослідженість особливостей ролі та значення державотворчих зу-

\footnotetext{
${ }^{1}$ Буковський І.В. Утворення і діяльність військових формувань Карпатської України (1938-1939): Автореф. дис... канд. іст. наук: 20.02.22; Нац. ун-т «Львів. Політехніка». Львів, 2004. 17 с.

2 Вегеш М. Велич і трагедія Карпатської України. Ужгород: Видавництво УжНУ «Говерла», 2007. 296 с.; Вегеш М. Гібридна війна польських диверсантів у Карпатській Україні (1938-1939). Європа і політика. Матеріали науково-практичної конференції «Україна - ЄС: двосторонні відносини у контексті загострення гібридної війни, конфлікту політик пам'яті та забезпечення прав національних меншин» (м. Ужгород, 3 травня 2018 р.). Ужгород, 2018. С. 57-62; Вегеш М. Гібридна війна угорських і польських терористів у Карпатській Україні (1938-1939). Актуальні проблеми політичної науки. Вип. 2. Ужгород: Видавництво УжНУ «Говерла», 2018. С. 88-103; Вегеш М. Державотворчі процеси у Карпатській Україні (1938-1939). Ужгород: Видавництво ПП «АУТДОР-ШАРК», 2020. 552 c.; Вегеш М., Вегеш І., Палінчак М., Голонич Я. Карпатська Україна в центральноєвропейській політичній кризі напередодні Другої світової війни. Фермонт, США, 2020. 272 с.

3 Віднянський С.В., Вегеш М.М. Августин Волошин і Карпатська Україна в історії українського державотворення: монографія. Київ: НАН України, Інститут історії України, 2021. 372 с.

4 Довганич О. Головний командант. Епізоди життя і діяльності Дмитра Климпуша за матеріалами кримінальної справи. Карпатська Січ. Матеріали науково-практичної конференції, присвяченої 56іŭ річниці Карпатської Січі / Редактор-упорядник проф. Василь Худанич. Ужгород: МПП «Гражда», 1996. С. 79; Довганич О.Д. Карпатська Україна в боротьбі за незалежність: репресії проти ії оборонців та керівників / післямова Миколи Вегеша. Ужгород: Гражда, 2007. 140 с.; Славік Ю.В. Репресії угорського окупаційного режиму в Карпатській Україні (весна 1939 р.). Науковий вісник Ужгородського університету. Серія: Історія, 2014. Вип. 2. С. 40-50.

5 Ковач Л. Суспільно-політичний розвиток Закарпаття у міжвоєнний період в оцінках вітчизняних і зарубіжних науковців. Наукові записки Інституту політичних і етнонаціональних досліджень ім. І.Ф. Кураса НАН Украӥни. 2017. Вип. 5-6. С. 302-321.

6 Петрецький В. Проблеми консолідації еліти Підкарпатської Русі другої половини 30-х років XX століття. Науковий вісник Ужгородського університету. Серія: Історія / Ужгород. націон. ун-т. Вип. 25. Ужгород: Вид-во УжНУ «Говерла», 2010. С. 147-151.

7 Цубов Л.В. Від Карпатської Русі до Карпатської України. «Демократичне врядування»: Науковий вісник. 2009. Вип. 3. URL: http://lvivacademy.com/vidavnitstvo_1/visnik3/fail/+Tsubov.pdf
} 
силь представників закарпатської політичної й духовної еліти у процесі проголошення та захисту Карпатської України.

Мета і завдання статті. 3 огляду на це, метою даної статті є дослідження участі закарпатської політичної і духовної еліти у процесі проголошення, розбудови та захисту Карпатської України, завданням статті $€$ характеристика сегментного складу та функціональних особливостей політичної і духовної еліти Закарпаття досліджуваного періоду, що зумовили можливість об'єднання різноманітних політичних течій навколо державотворення Карпатської України.

Основний матеріал. Фактичний розподіл території міжвоєнної Чехословаччини став каталізатором виходу на політичну авансцену цілої когорти представників закарпатської політичної та духовної еліти, котра до цього часу перебувала в орбіті впливу місцевої чехословацької адміністрації, проте відігравала значний вплив на динаміку самосвідомості українського населення регіону. Потрібно відзначити, що відносно нейтральне ставлення чехословацької адміністрації до політичної активності закарпатських елітних кіл з числа місцевих політичних і духовних діячів створило відповідний позитивний грунт для сегментованої консолідації місцевих національних еліт.

3 цього приводу В.В.Петрецький надає характеристику політичній атмосфері «передмюнхенського» Закарпаття та процесам консолідації місцевого політикуму. Так, вказаний науковець наголошує, що політична криза, котра поглибилася в Підкарпатській Русі у другій половині 1930-х рр., змусила місцеві політичні еліти прийти до думки про об'єднання політичних сил задля здобуття автономії. Загострення політичної боротьби зумовило не тільки необхідність відродження ефективної роботи Центральної Руської Народної Ради, а й пошуку компромісу та налагодження контакту між усіма учасниками політичного процесу. Внаслідок існування чіткої національно-політичної двоблокової системи (українці та русофіли) в Закарпатті виникли дві народні ради. Проте обидві ради прийшли до консенсусу 8 жовтня 1938 р., внаслідок чого утворився перший автономний уряд Підкарпатської Русі8. Отже, передумови консолідації закарпатської політичної еліти визначалися, з однієї сторони - міжнародним фактором, який зумовлював активізацію еліт в умовах наближення геополітичних змін, а з іншої сторони - прагненням домінування політичної течії, що у подальшому трансформувалося у співпрацю з опонентами.

Внаслідок досягнутого консенсусу політична еліта закарпатської автономії у складі Чехословаччини створила коаліційний уряд, який засвідчив здатність місцевих політичних діячів до досягнення спільного порозуміння. Як констатує M.М. Вегеш, 8 жовтня в Ужгороді була створена Національна Рада Підкарпатської Русі, до якої ввійшли Й. Камінський, В. Гомічков, М. Демко (Центральна Руська Народна Рада), А. Волошин, Ю. Бращайко, Д. Німчук (Перша Українська Народна Рада), А. Бродій, Ю.Фелдешій (Автономно-Землеробський Союз), Е. Бачинський, П. Коссей (Республіканська Землеробська партія), С. Фенцик (Руська НаціональноАвтономна партія), Ю. Ревай (Соціал-Демократична партія), І. П’єщак (АвтономноЗемлеробський Союз Пряшівщини), П. Жидовський (Республіканська Землеробська партія Пряшівщини). Таким чином, до складу Національної Ради Підкарпатської Русі увійшли представники всіх основних політичних сил краю9.

\footnotetext{
8 Петрецький В. Проблеми консолідації еліти Підкарпатської Русі... С. 147-151.

9 Вегеш М. Державотворчі процеси у Карпатській Україні (1938-1939)...
} 
Отже, «передмюнхенський» період кристалізації закарпатської політичної еліти демонструє наявність двох політичних течій серед еліти: русофільську (Руська Національно-Автономна партія), українофільську (Перша Українська Народна Рада), проте наявність представників землеробських автономістів і соціал-демократів дають підстави зробити висновок про існування проміжного центристського політикуму, який представляв інтереси соціальних верств, що були зорієнтовані на відповідні сфери: виробничу (соціал-демократи) й аграрну (аграрні союзи), що створювало відповідний баланс між полярними русофілами й українофілами.

Варто погодитися із Л.В. Цубовим, який характеризує процес боротьби за домінування у закарпатському політикумі представників української політичної еліти, яка стратегічно ефективно скористалася деструктивним впливом зовнішньополітичного чинника та змогла отримати домінування у краї. Вказаний дослідник зазначає, що ситуація, яка склалася в краї у 1938 р., все ближче підводила національно свідомих діячів українського руху до думки про об’єднання політичних сил української орієнтації в єдину національну організацію. Така постановка проблеми випливала, по-перше, з активізації русофільських політичних організацій. Подруге, польсько-угорські претензії щодо Закарпаття, як зовнішньополітичний чинник напруження в регіоні, також суттєво цьому сприяли.

У резолюції останнього Народного з'їзду Українського національно-демократичного об'єднання, який відбувся у січні 1938 р. у Галичині, події на Підкарпатській Україні характеризувались так: «Одиноко в Чехословацькій Республіці на Закарпатті, українське населення переживає часи свого стихійного національного відродження. У важких змаганнях, всупереч несприятливим умовинам та перепонам, які ставлять ворожі українській ідеї напливові чужонаціональні елементи та по-русофільські настроєні деякі чеські політичні чинники, - наш «поранений брат» виказує стільки життєвої енергії і національної свідомості. Що в останньому часі чесько-словацький уряд був приневолений започаткувати реалізацію автономії Закарпаття» 10.

У таких умовах політична еліта українофільських партій зосередилася навколо Першої Руської (Української) Центральної Народної Ради. Аналогічне об'єднання відбулося в русофільських автономних партіях, які зосередилися в Центральній Руській Народній Раді. У цей час, опинившись перед загрозою політичної анархії, спричиненою як кризою внутріполітичного життя в Чехословацькій Республіці, активізацією словацького автономізму, так і небезпечною для держави зовнішньополітичною ситуацією, представники політичних сил краю зуміли порозумітися в основних напрямах тогочасної політики і знайшли компроміс щодо утворення 14 жовтня 1938 р. першого автономного уряду Підкарпатської Русі на чолі з одним із лідерів русинофілів А. Бродієм. Українофільську орієнтацію у першому уряді представляли лише дві особи - міністр Ю. Ревай і державний секретар А. Волошин. Але дуже скоро співвідношення сил в уряді кардинально змінилося. Прем'єрміністра А. Бродія за його проугорську політику було заарештовано, а новий уряд очолив А. Волошин. Унаслідок цих змін в уряді та політичному житті автономного краю гору взяли українські еліти 11.

Отже, потрібно зазначити, що тільки радикальні дії проукраїнських політичних діячів у Закарпатті змогли забезпечити домінування проукраїнського політикуму та створити платформу для консолідації політичних і духовних діячів з метою подальших державотворчих ініціатив у надскладних геополітичних умовах.

10 Цубов Л.В. Від Карпатської Русі до Карпатської України...

11 Ibidem. 
Водночас варто констатувати, що середовище українських політичних діячів у процесі підготовки та проголошення незалежності «Карпатської України» суттєво страждало від кадрового голоду. Рушійною силою даного процесу була еліта, що сегментована на власне політичних, духовних і громадських діячів. Науковці зазначають, що відсутність у проукраїнському середовищі досвідчених політиків суттєво позначалася на ефективності державного будівництва.

Так, відомий діяч українського національно-визвольного руху на Підкарпатській Русі та української політичної еміграції у США В. Шандор (1907-2003) у ювілейній згадці про свого вчителя та наставника Олексу Приходька, зокрема, зазначає, що великі зміни у національно-культурному та політичному житті Карпатської України у XX ст. стали можливими «завдяки жертвенній та витривалій праці одиниць»12.

Безсумнівно, найбільш видатною постаттю у проголошенні та розбудові Карпатської України слід визначити закарпатського педагога, священика і вченого Августина Волошина (1874-1945). Варто погодитись із дослідниками у тому, що А. Волошин є однією з найвизначніших постатей історії Закарпаття міжвоєнного періоду (1919-1939). 3 його ім'ям пов'язане, перш за все, національно-культурне та політичне відродження закарпатських українців першої половини ХХ ст. Проте, у період радянської влади в Україні Августин Волошин був оголошений «ворогом народу». Через це на дослідження його різнобічної діяльності було накладено «табу», а у працях радянських істориків він зображувався винятково у негативному плані. Його зображували «запеклим українським буржуазним націоналістом», «слугою кількох господарів», «політичним авантюристом» тощо. Після розпаду СРСР та здобуття Україною державної незалежності відбувається переоцінка цінностей і повернення із забуття видатних постатей нашої історії, до яких, без сумніву, належить й Августин Волошин ${ }^{13}$.

Серед політичної еліти Карпатської України перебували і представники громадськості краю. Характеристики закарпатських парламентарів представлені у роботі О. Довганича «Карпатська Україна в боротьбі за незалежність: репресії проти їі оборонців та керівників»14. У ній зібрано біографічні довідки усіх 32 послів Сейму Карпатської України. Тривалий час імена цих людей перебували у цілковитому забутті. Майже половина з них були репресовані угорським і радянським режимами. Лише після здобуття Україною державної незалежності почали з'являтися окремі статті про їхні суспільно-політичні погляди та життєвий шлях ${ }^{15}$.

Зокрема, серед депутатів сейму Карпатської України угорських репресій зазнали І. Ігнатко, М. Марущак, І. Перевузник, П. Попович, К. Феделеш, а І. Грига після повернення з Хуста із засідання Сойму був розстріляний угорськими військовими. До тюрем також потрапили редактор головної урядової газети «Нова Свобода» В. Гренджа-Донський, голова партії УНО Ф. Ревай, секретар партії УНО А. Ворон, член штабу Карпатської Січі полковник В.Филонович, диригент Є. Шерегій, письменник О. Маркуш, провідник ОУН у Карпатській Україні Ю.Химинець, письменник У. Самчук і низка інших діячів Карпатської Січі, службовців Карпатської України та представників інтелігенції16.

Обраний Сеймом президент А. Волошин проголосив Карпатську Січ регулярною армією Карпатської України, став її головнокомандуючим. Начальником генштабу

\footnotetext{
12 Ковач Л. Суспільно-політичний розвиток Закарпаття у міжвоєнний період... С. 302-321.

13 Віднянський С.В., Вегеш М.М. Августин Волошин і Карпатська Україна...

14 Довганич О.Д. Карпатська Україна в боротьбі за незалежність...

15 Ковач Л. Суспільно-політичний розвиток Закарпаття у міжвоєнний період... С. 302-321.

16 Славік Ю.В. Репресії угорського окупаційного режиму в Карпатській Україні... С. 40-50.
} 
було затверджено полковника Сергія Єфремова. Окремим наказом був створений Штаб регулярної української армії з військових спеціалістів на чолі з полковником М. Гузаром-Колодзінським. Відтоді на Карпатську Січ, як на регулярну армію, поширювалася дія Женевських конвенцій стосовно ведення війни, охорони військовополонених, згодом грубо проігнорованих угорськими військовими злочинцями ${ }^{17}$. Подібна ситуація з утворенням збройних сил Карпатської України зумовила появу карпатоукраїнської військово-політичної еліти.

Складнощі реалізації державотворчої програми позначилися на взаєминах політичної і військової еліти Карпатської України. О. Довганич на підставі матеріалів кримінальної справи головного коменданта Карпатської Січі Д. Климпуша доводить, що у кінці лютого - березні 1939 р. Січ фактично перебувала в опозиції до уряду А. Волошина, підтримуючи ідейну платформу ОУН про створення української держави шляхом об'єднання усіх українських земель ${ }^{18}$. Подібні думки вміщено у спогадах низки політичних і громадських діячів Карпатської України, зокрема В. Шандора й ін. ${ }^{19}$

Після проголошення незалежності Карпатської України відбулася агресія Угорщини, у процесі якої угорській армії протистояла Карпатська Січ, в керівництві якою відбулися зміни. За відсутності Д. Климпуша, військовий міністр Карпатської України С.Клочурак призначив командантом Карпатської Січі полковника С. Єфремова. Що стосується С. Клочурака, то наказу про його призначення на посаду військового міністра в архівах не виявлено. Відомо, що газета «Нова свобода» 16 березня 1939 р. опублікувала склад уряду Карпатської України, в якому С. Клочурак займав посаду міністра з господарських питань. Можливо, що відсутність архівних матеріалів пояснюється тим, що ситуація в краї різко мінялася й уряд не мав часу займатися такими формальностями. Сучасний біограф С. Клочурака М. Мушинка вважає, що призначення його військовим міністром було закономірним і логічним. 3 таким твердженням необхідно погодитись, адже С. Клочурак мав військове офіцерське звання, а в період існування Гуцульської республіки доклав чимало зусиль для створення боєздатних збройних сил. Однак, погоджуємося із твердженням М.М. Вегеша й інших дослідників, у ситуації, яка склалася, врятувати становище було неможливо 20.

Значну роль у політичних процесах щодо проголошення та розбудови Карпатської України брала також місцева духовна еліта. Водночас, незважаючи на угрофільство більшості духовенства, у перші дні окупації краю угорцями гоніння зазнали також і представники місцевої Греко-католицької церкви. Траплялися навіть випадки знущань і вбивств священиків. Так сталося у с. Грушові, де 19 березня під час служби був заарештований місцевий священик о. К. Купар, якого 21 березня було розстріляно на Рахівщині. Вже через два дні після вступу угорської армії до Хуста під домашній арешт був взятий апостольський адміністратор Мукачівської єпархії єпископ Діонісій Няряді21. Жорстокого переслідування зазнали також ченці ордену св. Василія Великого, які займали чітку проукраїнську позицію22.

\footnotetext{
17 Буковський І.В. Утворення і діяльність військових формувань Карпатської України...

18 Довганич О. Головний командант... С. 79.

19 Мищак I. Закарпаття напередодні Другої світової війни у працях сучасних українських істориків. Історіографічні дослідження в Україні. 2008. Вип. 19. С. 410-421.

20 Вегеш М., Вегеш І., Палінчак М., Голонич Я. Карпатська Україна...

21 Ліхтей I. Єпископ Діонисій Наряді і Карпатська Україна (листопад 1938 - березень 1939). Дзвони. 1995. Ч. 4. С. 4-5.

22 Славік Ю.В. Репресії угорського окупаційного режиму в Карпатській Україні ... С. 42.
} 
Більшість представників духовенства, які брали участь у державотворчій діяльності при проголошенні й обороні Карпатської України, зазнавала системних репресій і в подальшому. Окрім зазначених представників духовенства Закарпаття, сам Президент Карпатської України отець А. Волошин був заарештований 15 березня 1945 р. у Празі радянськими спецслужбами і закінчив свої дні у тюрмах м. Москви через кілька місяців. С.В. Віднянський і М.М. Вегеш ${ }^{23}$ достеменно описують період перебування А. Волошина у тюремних установах й опис ставлення співробітників спецслужб до представників духовенства Карпатської України демонструє непримиренність реверсивного ставлення. Водночас дослідники ${ }^{24}$ констатують, що у порівнянні із довоєнним періодом, духовна еліта Карпатської України зазнала непоправних втрат у період радянізації Закарпаття після 1944 р., оскільки причетність до професійної діяльності (тобто служіння) у період Карпатської України стала головною фабулою вироків закарпатському духовенству.

Загалом до державотворців Карпатської України були ворожо налаштовані всі сусідні держави. Так, за матеріалами досліджень М.М. Вегеша 25 й інших науковців ${ }^{26}$, репресії, що спіткали українських політиків і духовенство Карпатської України, здійснювалися всіма державами, які межували з нею: Угорщині найбільш активно допомагали представники польської влади шляхом затримання та видачі карпатських «січовиків» і представників органів влади Карпатської України, що супроводжувалося передачею угорцями польській владі представників підпілля ОУН, які брали участь у захисті Карпатської України.

Висновки. Таким чином, роль закарпатської політичної та духовної еліти у проголошенні «Карпатської України» полягає у консолідації суспільно-політичних течій навколо державотворчих заходів. Закарпатська політична і духовна еліта спричинилася до процесу проголошення державності та проведення демократичних виборів до парламенту - Сойму з подальшим створенням урядових структур. Водночас особливими властивостями еліти були політико-світоглядні засади орієнтація на основоположні права людини, права націй на самовизначення, демократизм, етнонаціональний плюралізм. На наш погляд, причинами таких підходів став синтез політичних і духовних чинників, що уособлювала у собі, у першу чергу, постать А. Волошина.

Зазначені аспекти, побудовані на ліберально-християнських цінностях з однієї сторони і на цінностях українського державотворення та непохитної проукраїнської позиції - з іншої сторони, забезпечили достатньо ефективні в означених геополітичних умовах результати державотворення, коли за короткий термін було створено всі необхідні державні інституції і власні збройні сили. Подальша розбудова державності рекрутувала до даного процесу представників інших еліт - військової, дипломатичної, громадської, що сегментувало закарпатський політикум й у подальшому сформувало плеяду ефективних державників.

Воєнна агресія Угорщини зруйнувала український державотворчий процес і за-

\footnotetext{
23 Віднянський С.В., Вегеш М.М. Августин Волошин і Карпатська Україна...

24 Василина Н. Карпатська Україна в міжнародних відносинах напередодні Другої світової війни. Нове бачення подій. Ужгород: Всеукраїнське державне видавництво «Карпати», 2008. 224 с.

25 Вегеш М. Велич і трагедія Карпатської України...; Вегеш М. Гібридна війна польських диверсантів у Карпатській Україні (1938-1939)... С. 57-62; Вегеш М. Гібридна війна угорських і польських терористів у Карпатській Україні (1938-1939)...

26 Гиря В. Угорська іредента в міжвоєнному Закарпатті («угорський фактор» у суспільнополітичному житті). Ужгород: Всеукраїнське державне видавництво «Карпати», 2012. 200 с.
} 
вдала нищівного репресивного удару по закарпатській політичній і духовній еліті, яка розбудовувала українську державність. Водночас, даний процес здійснювався за підтримки громадсько-політичної еліти Східної Галичини, роль і участь якої у процесі українського державотворення на Закарпатті досліджуваного періоду виступає перспективою подальших досліджень.

\section{REFERENCES}

Bukovskyi, I.V. (2004). Utvorennia i diialnist viiskovykh formuvan Karpatskoi Ukrainy (1938-1939) [Formation and activity of military formations of Carpathian Ukraine (1938-1939)]. (Extended abstract of Candidate's thesis). Lviv [in Ukrainian].

Dovhanych, 0. (1996). Holovnyi komandant. Epizody zhyttia i diialnosti Dmytra Klympusha za materialamy kryminalnoi spravy [Chief Commander. Episodes of Dmytro Klympush's life and activity based on the materials of the criminal case]. In Khudanych, V. (Ed.). Karpatska Sich. Materialy naukovo-praktychnoi konferentsii, prysviachenoi 56-i richnytsi Karpatskoi Sichi, (p. 79). Uzhhorod: Hrazhda [in Ukrainian].

Dovhanych, O.D. (2007). Karpatska Ukraina $v$ borotbi za nezalezhnist: represii proty yii oborontsiv ta kerivnykiv [Carpathian Ukraine in the struggle for independence: repression against its defenders and leaders]. Uzhhorod: Hrazhda [in Ukrainian].

Hyria, V. (2012). Uhorska iredenta v mizhvoiennomu Zakarpatti («uhorskyi faktor» u suspilnopolitychnomu zhytti) [Hungarian irredent in interwar Transcarpathia («Hungarian factor» in sociopolitical life)]. Uzhhorod: Karpaty [in Ukrainian].

Kovach, L. (2017). Suspilno-politychnyi rozvytok Zakarpattia u mizhvoiennyi period v otsinkakh vitchyznianykh i zarubizhnykh naukovtsiv [Socio-political development of Transcarpathia in the interwar period in the assessments of domestic and foreign scientists.]. Naukovi zapysky Instytutu politychnykh i etnonatsionalnykh doslidzhen im. I.F. Kurasa NAN Ukrainy, 5-6, 302-321 [in Ukrainian].

Likhtei, I. (1995). Yepyskop Dionysii Nariadi i Karpatska Ukraina (lystopad 1938 - berezen 1939) [Bishop Dionysius Naryadi and Carpathian Ukraine (November 1938 - March 1939)]. Dzvony, 4, 4-5 [in Ukrainian].

Myshchak, I. (2008). Zakarpattia naperedodni Druhoi svitovoi viiny u pratsiakh suchasnykh ukrainskykh istorykiv [Transcarpathia on the eve of World War II in the works of modern Ukrainian historians]. Istoriohrafichni doslidzhennia v Ukraini, 19, 410-421 [in Ukrainian].

Ofitsynskyi, R. (2019). Suchasni uiavlennia pro Karpatsku Ukrainu [Modern ideas about Carpathian Ukraine]. Ukrainske derzhavotvorennia, 1, 44-47 [in Ukrainian].

Petretskyi, V. (2010). Problemy konsolidatsii elity Pidkarpatskoi Rusi druhoi polovyny 30-kh rokiv XX stolittia [Problems of consolidation of the elite of Subcarpathian Russia in the second half of the 1930s]. Naukovyi visnyk Uzhhorodskoho universytetu. Ser. Istoriia, 25, 147-151 [in Ukrainian].

Slavik, Yu.V. (2014). Represii uhorskoho okupatsiinoho rezhymu v Karpatskii Ukraini (vesna 1939 r.) [Repressions of the Hungarian occupation regime in Carpathian Ukraine (spring 1939)]. Naukovyi visnyk Uzhhorodskoho universytetu. Ser. Istoriia, 2, 40-50 [in Ukrainian].

Tsubov, L.V. (2009). Vid Karpatskoi Rusi do Karpatskoi Ukrainy [From Carpathian Russia to Carpathian Ukraine]. Demokratychne vriaduvannia, $3 . \quad$ Retriefed from http://lvivacademy.com/vidavnitstvo_1/visnik3/fail/+Tsubov.pdf [in Ukrainian].

Vasylyna, N. (2008). Karpatska Ukraina v mizhnarodnykh vidnosynakh naperedodni Druhoi svitovoi viiny. Nove bachennia podii [Carpathian Ukraine in international relations on the eve of World War II. A new vision of events]. Uzhhorod: Karpaty [in Ukrainian].

Vehesh, M. (2020). Derzhavotvorchi protsesy u Karpatskii Ukraini (1938-1939) [State-building processes in Carpathian Ukraine (1938-1939)]. Uzhhorod: AUTDOR-ShARK [in Ukrainian].

Vehesh, M. (2018). Hibrydna viina polskykh dyversantiv u Karpatskii Ukraini (1938-1939) [Hybrid war of Polish saboteurs in Carpathian Ukraine (1938-1939)]. Yevropa i polityka. Proceedings of the Conference: «Ukraina - YeS: dvostoronni vidnosyny u konteksti zahostrennia hibrydnoi viiny, konfliktu polityk pamiati ta zabezpechennia prav natsionalnykh menshyn», (pp.57-62). Uzhhorod [in Ukrainian].

Vehesh, M. (2018). Hibrydna viina uhorskykh i polskykh terorystiv u Karpatskii Ukraini (1938-1939) [Hybrid war of Hungarian and Polish terrorists in Carpathian Ukraine (1938-1939)]. Aktualni problemy politychnoi nauky, 2, 88-103 [in Ukrainian].

Vehesh, M. (2007). Velych i trahediia Karpatskoi Ukrainy [The greatness and tragedy of Carpathian Ukraine]. Uzhhorod: Hoverla [in Ukrainian]. 
Vehesh, M., Vehesh, I., Palinchak, M. \& Holonych, Ya. (2020). Karpatska Ukraina $v$ tsentralnoevropeiskii politychnii kryzi naperedodni Druhoi svitovoi viiny [Carpathian Ukraine in the Central European political crisis on the eve of World War II]. Fermont, SShA [in Ukrainian].

Vidnianskyi, S.V. \& Vehesh, M.M. (2021). Avhustyn Voloshyn i Karpatska Ukraina v istorii ukrainskoho derzhavotvorennia [Augustyn Voloshin and Carpathian Ukraine in the history of Ukrainian state formation]. Kyiv: NAN Ukrainy, Instytut istorii Ukrainy [in Ukrainian].

\section{Andrii Sinitskyi}

(Polissia National University, Zhytomyr, Ukraine)

e-mail: andriysinc@gmail.com

ORCID: https://orcid.org/0000-0002-6482-4055

\section{The Role of Transcarpathian Political and Church Elite in Proclamation of Carpathian Ukraine}

The participation of Transcarpathian political and church elite in the process of proclamation, development, and defense of Carpathian Ukraine is studied in the paper. Based on the principles of historicism, as well as complexity and scientific objectivity, the author of the paper analyzes the specific historical preconditions for the formation of Transcarpathian political and church elite in the geopolitical processes of the early $20^{\text {th }}$ century. The determining peculiar factors of political differentiation and social segmentation of Transcarpathian political elite of the studied period are outlined, on the basis of which the segmental composition and functional features of Transcarpathian political and church elite in the period between the two world wars are characterized. In the process of historical reconstruction and analytical interpretation, general and special research methods were used, including problemchronological method, methods of historiographic analysis and synthesis, retrospective method, which generally made it possible to specify the cause-effect relations between the factors which had influenced the formation of political and the church elite, as well as the role and importance of the representatives of that elite in the state-building process during the preparation, proclamation, and defense of Carpatho-Ukrainian statehood in 1939.

The political conditions in which the representatives of the political and church elite carried out their state-building activities are characterized in the paper. The social basis of the political and church elite is represented, and the transformation of the relations of the main social and political groups is shown. Functional analysis of the participation of individual representatives of the political and church elite in the proclamation of Carpathian Ukraine, the formation of public authorities, and the defense of the restored statehood is presented. The place and value of the international factor's influence on the state-building process and the role of the local political and church elite in that process in Ukrainian Transcarpathia in the second half of the 1930s are characterized in detail. Particular attention is paid to the factors that led to the possibility of uniting various political groups around the state formation of Carpathian Ukraine, and the effectiveness of the political and spiritual factors consolidation in this process is proved.

Keywords: Carpathian Ukraine, Carpathian Sich, political elite, church elite, state formation 